ISSN 0975-3311

UJBM, Vol. 8, No. 2, July - December 2009, pp 9-23

https://doi.org/10.12725/ujbm.15.2

\title{
A STUDY OF POLITICAL STYLES OF MANAGERS IN PUBLIC \& PRIVATE ORGANIZATIONS
}

\author{
Harold Andrew Patrick*
}

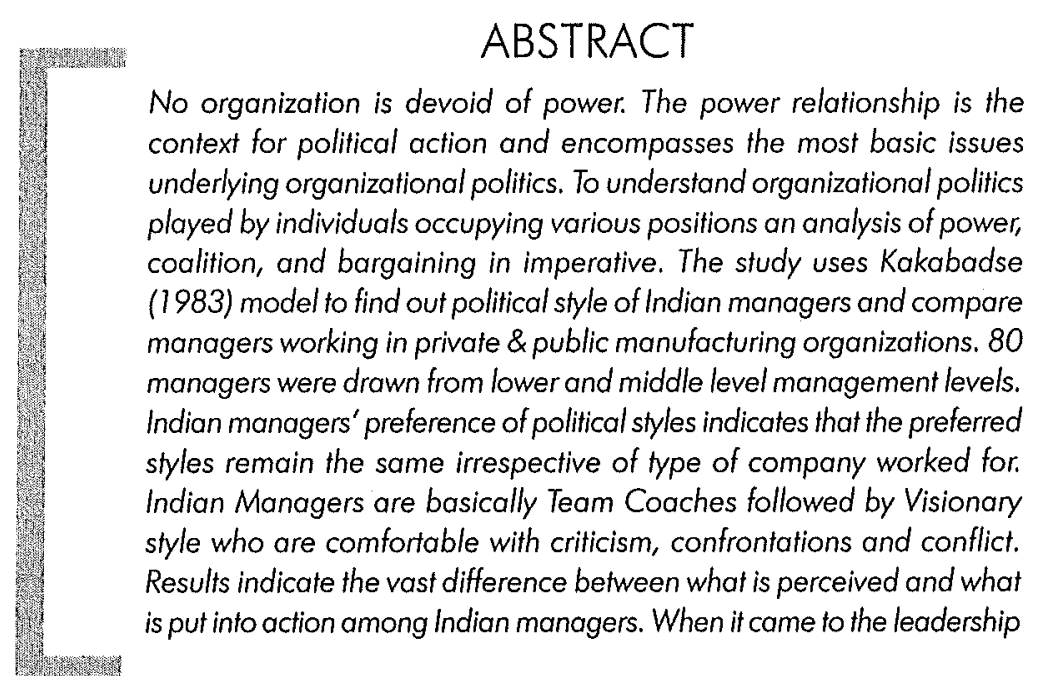

* Christ University Institute of Management, Bangalore. Email: haroldpatrick@christuniversity,in 
style adopted it was found that the Participative style was the least adopted style in actual work situation. The results are discussed in the context of Indian manufacturing organizations.

Key Words: Traditionalist, Team Coach, Company Baron, and Visionary.

\section{Introduction}

There is evidence that power systems were well developed when known history began. Robert Ardrey (1962) described power structures among lower animals. Today's organizations could be perceived as politically negotiated orders and not as rational, harmonious entities classified in managerial theory, or areas of class conflict as proposed by Marx. It can be observed that actors in their daily transactions perpetually bargain, repeatedly form and reform coalitions, and constantly avail themselves of influence tactics.

In Indian organizations managers practice a variety of political styles to get work done. Managers' preference of the political style may differ or be in concert with the overall management or organization style. In reality at the end of the getting work done effectively and efficiently is more important than how you got it done. Because survival in an organization is a political act, managers in organizations involve themselves in the tactical use of power to retain and or to obtain control of real or symbolic resources. Organizational structures are emergent entities, i.e., they are the result of the conscious political decisions of particular actors and / or interest groups.

As no organization is devoid of power, managerial politics is specific to the position and the characteristics of the person in that position. This is the determining factor in how managers get work done. The most dynamic factor that influences organizations in successfully achieving their goals is the political behaviour of its members.

Power is one of the most important motive or disposition that individuals strive for. These political behaviour though unseen and not sanctioned by organizations dominate the working relations between supervisors \& subordinates to a great extent. Organizations can be perceived as politically negotiated orders and not as rational, harmonious entities, or as areas of class conflict. 
Power is an inescapable part of management (Torrington, Weightman, \& Johns (1988)). Organizational charges are mainly provided to describe the formal allocation of power to job titles. If there were always total agreement about objectives and how to achieve them, there would be no need to change or influence others, with or without the use of power.

Derived from the Latin root poteré meaning 'to be able'; three qualifications need to be made to give a useful definition of power. Firstly, when one or more persons have an effect on the behaviour or emotions of another person or persons, that can be inferred from observation of behaviour. Secondly, that someone has an ability or can produce an effect strongly suggests that he can do something when, how, and in the way that he wants to do it - according to his intension, and Thirdly, Social power can be thought of as a capacity as well as an action. Thus it is the ability or capacity of a person $(O)$ to produce (consciously or unconsciously) intended effects on the behaviour or emotions of another person (P).

Kakabadse (1983) identifies two fundamental drives which lead to the formation of mental maps - people's perception and their actions. The model shows the dominant values people hold, the attitudes they adopt and the styles they use to put their values and attitudes into practice.

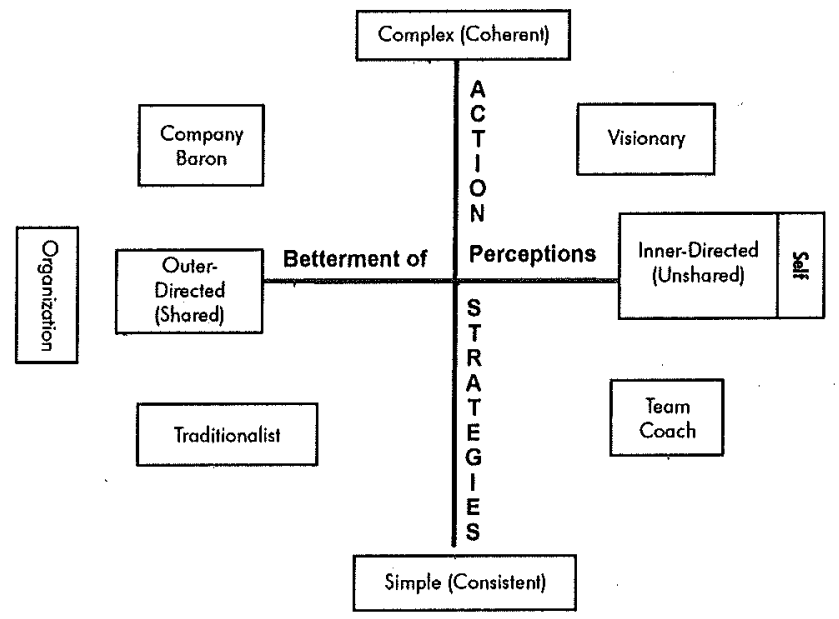

Fig: 1.2 Perception / action model, showing the dominant values people hold and the attitudes they adopt.

Source: Kakabadse (1983). The politics of management. 
Perceptions: The horizontal axis represents the determinants of people's perceptions, i.e., their values or beliefs, probably the most powerful factors in personality.

The two extreme ends of the continuum are inner directedness i.e., people who develop their perceptions and views with little references to the outside world and outer- directedness i.e., people who feel a need to comply with the perceived attitudes and behaviour that others seem to exhibit in that situation.

Actions: The vertical axis represents people's abilities to put into practice their views \& values, i.e., their repertoire of action strategies. The two alternative types of action strategies are simple-people who aim for consistency, irrespective of whether the people in the situation work on shared or unshared meaning, the behaviours they feel they should adopt are predictable, commonly recognized and probably previously practiced. Complex action strategies involve people behaving in ways that they consider suitable to meet only their needs in the situation. The pattern of behaviour may be inconsistent but coherent, i.e., it makes sense once one knows the individual \& or his desired objectives.

The combination of the inner / outer directed axis \& the simple / complex action strategies axis forms the individual's mental maps. The type of mental maps held by an individual will indicate the quality \& the way individuals get work done \& interact. Thus the differences in these mental maps gives rise to the action of power i.e., politics, making politics in organizations inevitable.

As a result of having observed managers at work Kakabadse (1983) has developed four particular behaviour patterns: Traditionalist, Team Coach, Company Baron, and Visionary.

Traditionalists wish to fit in with the rest of the organization. They accept the fact that they are dependent on the objectives provided by others, and the way resources are allocated, even if it is detrimental to their interests. If resources were allocated in the past in a particular way, then that is the way it ought to continue.

The Team Coach develops his own ideas \& beliefs as to how he would wish to conduct his life and affairs. However, independence of thought is not matched by independence of action. He needs to belong to a group 
of like minded people and after becoming one, may see himself as a missionary, whose calling is to shift the predominant values of the organization nearer to the values of the group. He would be sincere in his attempts to help others in the organization experience the same degree of work satisfaction as he does with his group.

The Company Baron has the ability to see the total organization as it really is; and has a continuous strong drive to enhance his position and, if need be, emphasize and amplify his role at the expense of others.

The visionary is one who is similar to the Company Baron and who possesses the ability to see the organization in total. He can think and conceptualize in whole organizational terms, he does not feel the same need for loyalty to the organization. He questions and examines the way resources are allocated in organization but he also explores what are suitable structures for the Organization. He can stand back from the values, views and stereotypes held by the majority in the organization. Such independence of mind is invaluable, if faced with reorganization and restructuring.

The way to manage politics is by influencing individuals and groups of people to our point of view. Being in a position is not sufficient. We may want others to accept our idea, do what we want them to or simply get them to re-examine what they are doing so that they can improve their performance. An unacceptable boss finds that he is blocked, out-maneuvered or even out-talked by smarter subordinates. What is required then is to influence others sufficiently to accept one's particular ideas and efforts. The seven approaches to effective interpersonal influence are: 1. Identify the stakeholders; 2 . Keep the stakeholders comfortable; 3 . Fit the image; 4. Use the network; 5 . Make deals; 6. Withhold and withdraw; and 7 . If all else fails...

OBJECTIVE: The objective of the study was to use the Kakabadse (1983) model as a tool to find out which political style Indian managers in Private \& Public manufacturing organizations adopt to get things done.

PROBLEM: To study the political styles adopted by Indian managers in Public and Private manufacturing organizations.

HYPOTHESIS: There will be significant differences in the perception of political styles and adopted styles in reality to get work done between Private \& Public manufacturing organizations. 
SAMPLE: 80 Managers were randomly selected from manufacturing organizations. 40 from Public and 40 from Private organizations.

\begin{tabular}{|l|c|c|c|}
\hline & Private & Public & Total \\
\hline Middle Level & 20 & 20 & 40 \\
Lower Level & 20 & 20 & 40 \\
Total & 40 & 40 & 80 \\
\hline
\end{tabular}

\section{TOOLS ADOPTED:}

1. The political styles questionnaires by Kakabadse, A (1983) was adopted. It consists of four styles: 1. Traditionalist 2. Team Coach 3. Company Baron 4. Visionary

2. An open ended questionnaire was developed to seek information about the various techniques adopted by managers to get work done at the work place.

The above questionnaire was content analyzed and the following techniques were identified: 1. Democratic 2. Autocratic 3. Participative 4. Manipulative The Statistical techniques employed were simple means, standard deviations and percentages.

\section{Results}

Table 1: Indicates the mean scores \& the standard deviation for *L.L.M.'s \& **M.L.M.'s (Private) on political styles.

\begin{tabular}{|l|c|c|c|c|}
\hline \multirow{2}{*}{ Political Styles } & \multicolumn{2}{|c|}{ LLM's } & \multicolumn{2}{c|}{ MLM's } \\
\cline { 2 - 5 } & Mean & S.D & Mean & S.D \\
\hline Traditionalist & 11.80 & 06.80 & 08.25 & 10.02 \\
Team Coach & 21.40 & 22.05 & 20.25 & 25.75 \\
Company Baron & 20.70 & 21.30 & 17.15 & 17.66 \\
Visionary & 16.10 & 12.75 & 24.35 & 25.75 \\
\hline
\end{tabular}


Table 2: Indicates the mean scores and the standard deviation for LLM's \& MLM's (Public) on political styles:

\begin{tabular}{|l|c|c|c|c|}
\hline \multirow{2}{*}{ Political Styles } & \multicolumn{2}{|c|}{ LLM's } & \multicolumn{2}{c|}{ MLM's } \\
\cline { 2 - 5 } & Mean & S.D & Mean & S.D \\
\hline Traditionalist & 14.15 & 17.00 & 12.25 & 13.11 \\
Team Coach & 20.85 & 21.15 & 21.05 & 21.21 \\
Company Baron & 17.30 & 18.39 & 18.35 & 18.97 \\
Visionary & 17.70 & 19.93 & 19.35 & 19.44 \\
\hline
\end{tabular}

Table 3: Indicates the combined mean scores \& the standard deviation for Private and Public organization on political styles:

\begin{tabular}{|l|c|c|c|c|}
\hline \multirow{2}{*}{ Political Styles } & \multicolumn{2}{|c|}{$\begin{array}{c}\text { Private Organization } \\
\text { LLM's }+ \text { MLM's }\end{array}$} & \multicolumn{2}{c|}{$\begin{array}{c}\text { Public Organization } \\
\text { LLM's }+ \text { MLM's }\end{array}$} \\
\cline { 2 - 5 } & Mean & S.D & Mean & S.D \\
\hline Traditionalist & 10.03 & 06.63 & 12.70 & 15.32 \\
Team Coach & 20.63 & 07.25 & 20.95 & 21.44 \\
Company Baron & 18.61 & 06.53 & 17.83 & 5.34 \\
Visionary & 20.73 & 19.35 & 18.52 & 19.90 \\
\hline
\end{tabular}

Table 4: Indicates adopted styles used in getting work done in actual work situations in percentages for LLM's \& MLM's (Private)

\begin{tabular}{|l|c|c|}
\hline Styles & LLM's (\%) & MLM's (\%) \\
\hline Democratic & $20 \%$ & $15 \%$ \\
Autocratic & $35 \%$ & $40 \%$ \\
Participative & $10 \%$ & $10 \%$ \\
\hline
\end{tabular}


Table 5: Indicates adopted styles used in getting work done in actual work situations in percentages for LLM's \& MLM's (Public)

\begin{tabular}{|l|c|c|}
\hline Styles & LLM's (\%) & MLM's (\%) \\
\hline Democratic & $10 \%$ & $10 \%$ \\
Autocratic & $40 \%$ & $25 \%$ \\
Participative & $00 \%$ & $15 \%$ \\
\hline
\end{tabular}

Table 6: Indicates combined adopted styles used in getting work done in actual work situations in percentages for Private \& Public Organizations:

\begin{tabular}{|l|c|c|}
\hline Styles & LLM's (\%) & MLM's (\%) \\
\hline Democratic & $17.5 \%$ & $10 \%$ \\
Autocratic & $37.5 \%$ & $32.5 \%$ \\
Participative & $10 \%$ & $07.5 \%$ \\
Manipulative & $35 \%$ & $50 \%$ \\
\hline
\end{tabular}

${ }^{*}$ LLM's $=$ Lower Level Managers ${ }^{* *}$ MLM's = Middle Level Managers

\section{Discussion}

The combined means of Indian managers on their preference of political styles indicate that whether you work in Public or Private manufacturing organizations, the preferred styles remain the same.

Indian Managers are basically Team Coaches who are comfortable with introduction of new style to the group. They help in developing potential in the group. They adopt consensual decision - making patterns with respect to changes in work patterns, small changes in resource allocation \& tasks. Team coaches are uncomfortable with people who dramatically threaten the unity of the group \& criticize non-consensual patterns of decision making.

The backup style is the Visionary style who are comfortable with criticism, confrontations and conflict. They use personal influencing skills and their affiliations with people is low. They like new, innovative \& risky ideas and working in poorly structures situations. They like to work in large scale change, controlling people \& projects. They are uncomfortable with detail 
\& routine work, working within role constraints \& established procedures, display of warmth from others, lengthy decision making processes, maintaining group cohesion for its own sake, remaining with one job, organization or well developed career hierarchy for too long.

The least preferred style is the Traditionalist style by the groups, who are comfortable with maintenance of superior-subordinate distance. They are comfortable with small recognizable groups of acquaintances developed over time by them. They like to be given directions and standards required for tasks. They supervise well structured tasks. They like administrative tasks, routine, established procedures and detail and keep to the status quo. They are uncomfortable with changes of work pattern, loss of organization structure, confrontation, too much discussion about ideas and developments for the future, involvement in major decision making and supervising poorly structured tasks.

From the above results it could be inferred that Indian managers adjust to the complex (coherent) \& single (consistent) action strategies and are inner directed (unshared) in their determinants of perceptions which involves the self and thus preferred Team Coach and the Visionary style as the dominant and the backup styles to get work done. They did not prefer the complex (coherent) or the single (consistent) action strategies that is outer-directed (shared) determinants of perceptions that include the Traditionalist and Company Baron styles.

The only difference in the groups is found in Private manufacturing organizations between LLM's and MLM's. The former group preferred Team Coach as the dominant style and Company Baron as the backup style. The latter group preferred Visionary as the dominant style and Team Coach as the backup style.

Though Indian managers perceived cognitively a particular style to get things done in reality what they do is entirely different in real work situations.

Table 6 indicates the combined percentages on styles adopted to get work done by Private \& Public organizations. The percentages indicate that in real work situations managers in Private organizations adopted the Autocratic style followed by Manipulative style. Public organizations managers adopted the Manipulative style followed by Autocratic style. The Participative style was the least adopted style in actual work situation. 


\section{Conclusion}

The above results indicate the vast difference between what is perceived and what is put into action among Indian managers. Indian managers to a large extent don't practice what they preach. Indian organizations culture and climate may have contributed to this gap between what it professes to its managers and what managers do because of their personality.

Compared to their Western counterparts, Indian organizations have some unique characteristics. The task and the technology determine to a great extent available size and structure, authority pattern, division of labor, departmental differentiations, communication network, work procedures etc. Though organizations do differentiate themselves from the environment, the individuals in it still have and do maintain identities. Individuals do not forget their cultural roots and orientations. They are often reflected in the life of an organization.

An effective manager can manage effectively only by understanding and using power in an appropriate manner to get work done. Survival in an organization is a political act and it is to obtain and / or control real or symbolic resources. Managers though have laid out procedures on how to get work done because of their personality may opt for ways they strongly believe in to get work done in reality. This inconsistency and paradox is evident in this research.

As this was an exploratory study using the Kakabadse model for the first time. A larger sample may have to be studies to confirm the results. How Indian organizations nurture power should be studied. It can be said that Top level managers if studies may confirm to the findings of this study.

The above study would like to highlight some unsettled questions of power and its use in organizations.

1. How does one best organize a group so that the activities of its members are coordinated?

2. Why do so many people react to leaders by displaying either dependence or defiance?

3. Is it possible for groups to be effective without concentrating power in the hands of very few people? 
4. How can one keep a group from destroying the individuality and personal freedom of its members?

5. Must strong groups always exploit weaker ones?

Understandably, many people may fear the politics played within organizations. Equally, many people may not wish to play politics. Whatever each individual decides, atleast one should not be afraid of being political. Politics is not all negative and bad. At the general psychological level, power corrupts but also uplifts life. At the Sociological level, power is both integrative and divisive. A Society without a power structure is inconceivable at least on earth. Man cannot function with his power motive castrated, at least not as a healthy man.

\section{Bibliography}

Abadalla, I. A. (1984). Predictors of the effectiveness of supervisory social power. Human Relations, Vol. 40(11), November, 721-739.

Abdel-Halim, A. A. (1983). Power equalization, participative decision - making, and individual differences. Human Relations, Vol. 36(8), August, 683-704.

Abdel-Halim, A. A. (1979). Interaction effects of power equalization and subordinate personality on job satisfaction and performance. Human Relations, Vol. 32, No. 6, 489-502.

Aguinis, H., Nesler, M. S., Quigley, B. M., and Tedeschi, J. T. (1994). Perceptions of power: A cognitive perspective. Social Behaviour and Personality, 22 (4), 377-384.

Assor, A. (1988). Types of power motivations, sense of security and style of power-seeking in groups. Psychological Reports, Vol. 63(1), August, 91-105.

Astley, W. G. (1977). Sources of power in organizational life. Ph. D. thesis, University of Washington. As abstracted in the dissertation abstracts international. A, The Humanities and Social Sciences, Vol. 39(7), January, 1979.

Bacharach, S. B., and Lawler, E. J. (1980). Power and politics in organizations: The social psychology conflict, coalitions and bargaining. Jossey-Bass Publishers.

Bass, B. M., Bruce, J. A.; Dong, I. J., and Yair, B. (2003). Predicting unit performance by assessing transformational and transactional leadership. Journal of Applied Psychology, $88,207-218$.

Bass, B. M., (1990). Bass and Stogdill's Handbook of Leadership: Theory, research, and managerial applications. New York: The Free Press. 
Brass, D. J., and Burkhardt, M. E. (1993). Potential power and power use: An investigation of structure and behaviour. The Academy of Management Journal, Vol. 36(3), June, $441-470$.

Cartwright, D. (1959). Studies in social power. The University of Michigan Press.

Chakraborty, S.K., and Bhattacharya, Pradip. (2001). (Eds), Leadership and power: Ethical explorations. Oxford University Press.

Clegg, S. (1979). The theory of power and organization. Routledge and Kegan Paul.

Dahl, R. A. (1957). The concept of Power. Behavioural Science, 2, 201-218.

Dale, K., and Fox, M. L. (2008). Leadership style and organizational commitment: Mediating effect of role stress, Journal of Managerial Issues, Spring, Vol. 20 (8), 109-130.

Das, G. S., and Cotten, C. C. (1988). Power balancing styles of Indian managers. Human Relations, Vol. $41(7)$, July, 533-551.

Diamond, M. A., and Allcorn, S. (1986). Role formation as defensive activity in bureaucratic organizations. Political Psychology, Vol. 7(4), December, 709-732. As abstracted in the American Psychological abstracts, Vol. 75(4), April, 1988.

Dick, R. V., Hirst, G., Grojean, M. W., and Wieseke, J. (2007). Relationships between leader and follower, organizational identification and implications for follower attifudes and behaviour. Journal of Occupational and Organizational Psychology, 80, 133-150.

Dunnette, M. D. (1976). Handbook of Industrial and Organizational Psychology. Rand Mcnally college publishing company, Chicago.

Eisenhardt, K. M., and Bourgeois, L. J. (1988). Politics of strategic decision-making in highvelocity environments: Towards a midrange theory. Academy Of Management Journal, Vol. 31 (4), December, 737-770. As abstracted in the American Psychological abstracts, Vol. 76(5). May, 1989.

Greenberg, J., and Robert A. B. (2000). Behaviour in organizations: Understanding and managing the human side of work. Upper Saddle River, NJ: Prentice-Hall.

Gupta, B., and Sharma, N. K. (2008). Compliance with bases of power and subordinates' perception of superiors: Moderating effect of quality of interaction. Singapore Management Review, Vol 30(1).

Hendrix, W.H., and Stahl, M. J. (1986). Effects of need for power on job stress for managers and non-managers. Journal of Social Behaviour and Personality, Vol. 1 (4), October, 611-619. As abstracted in the American Psychological abstracts, Vol. 75(3), March, 1988.

Hooijberg, R., and Choi, J. (2001). The impact of organizational characteristics on leadership effectiveness models: An examination of leadership in a private and a public sector, Organization Administration and Society, Vol. 33(4), 403-431. 
Jones, S. (1987). Organizational politics: only the darker side? Management Educations and Development, Vol. 18(2), Summer, 116-128. As abstracted in the American Psychological abstracts, Vol. 75(8), August, 1988.

Katz, D., and Kahn, R. L. (1966). The Social Psychology of Organizations. Wiley Eastern Private Limited.

$\mathrm{Kim}, \mathrm{H}$. and Cervero, R. M. (2007). How power relations structure the evaluation process for HRD programmes. Human Resource Development International, March, Vol. 10(1), 5-20.

Kinicki, A., and Robert K. (2008). Organizational behaviour. Boston, MA: McGraw-Hill Inwin.

Kotter, J. P. (1978). Power, successes and organizational effectiveness. Organizational Dynamics, Vol. 6(3), Winter, 26-40. As abstracted in the American Psychological abstracts, Vol. 61 (4), April, 1979.

Krishnan, V. R., and Arora, P. (2008). Determinants of transformational leadership and organizational citizenship behaviour. Asia-Pacific Business Review, January - March, Vol. 4(1), 34-43.

Krishnan, V. R., and Sivakumar, R. (2004). Impact of top management power on corporate divestiture, corporate governance. The International Journal of Business in Society, Vol 4(1), 24-30.

Kruglanski, A. W., Pierro, A., and Higgins, E. T. (2007). Regulatory mode and preferred leadership styles: How fit increases job satisfaction. Basic and Applied Psychology, Vol. 29(2), 137-149.

Lo, M. C., Ramayah, T., and Min, C. L. (2007). Bases of power and job salisfaction. Icfai Journal of Organizational Behaviour, Vol. 6(1), January, 41-54.

Luthans, F. (2008). Organizational behaviour. Boston, MA: McGraw-Hill Irwin.

Morrell, K. and Hartley, J, A. (2006). Model of political leadership. Human Relations, Vol. 59(4), 483-504.

Mossholder, K. W., Bennet, N., Kemery, E. R. and Wesolowski, M. A. (1998). Relationships between bases of power and work reactions: The mediational role of procedural justice, Journal of Management, Vol. 24(4), 513-552.

Munduate, L., and Dorado, M. A. (1998) Supervisor power bases, co-operative behaviour, and organizational commitment. European Journal of Work and Organizational Psychology, Vol. 7(2), 63-177.

Ne, S. H. (1980). The Social Psychology of Power. Academic press.

Politis, J. D. (2003). The effect of managerial power and relational trust on the skills and Iraits of knowledge acquisition: Evidence from the United Arab Emirates. Electronic 
'Journal on Knowledge Management, Vol.1(2), 147-158, Academic Conferences Limited.

Preston, J. C. (1988). Power and politics, A necessity in large system change. Organization Development Journal, Winter, Vol. 6(4), 46-52. As abstracted in the American Psychological abstracts, September, Vol. 76(9), 1989.

Rahim, M. A. (2004). Leader power, followers' conflict management strategies, and propensity to leave a job: A cross-cultural study. Paper presented at the annual conference of international association for conflict management, Pittsburgh.

Rahim, M. A. (1989). Relationships of leader power to compliance and satisfaction with supervision: Evidence from a national sample of managers. Journal of Management, Vol.15(4), 545-556.

Roberts, N. C. (1986). Organizational power styles, collective and competitive power under varying organizational conditions. Journal of Applied Behavioural Sciences, Vol. 22(4), 443-458. As abstracted in the American Psychological abstracts, June, Vol. 74(6), 1987.

Rosenzwing, R. M., and Porter W. L. (1987). The need for power and managerial performance. Annual Review of Psychology, Vol. 38.

Schjelderup-Ebbe, T. (1935). Social behaviour of birds. In Carl Murchison (Ed.), A Handbook of Social Psychology, (pp. 947-972). Worcester.

Singh, N., and Krishnan, V. R. (2007). Transformational leadership in India: Developing and validating a new scale using grounded theory approach. International Journal of Cross Cultural Management, Vol. 7(2), 219-236.

Singh, R. P., and Pandey, J. (1988). Choosing a base of power through routinized rewards. Vikalpa, January-March, Vol. 13(1), 63-67.

Singh, S. (2004). Power dynamics: managers' power and perception of their subordinates' behaviour. Journal of the Academy of Business and Economics, January.

Singh, S. (1986). Values and personality correlates of projective measure of power motivation. British Journal of Projective Psychology and Personality Study, June, Vol. 31 (1), 32-38. As abstracted in the American Psychological abstracts, January, Vol. 75(1), 1988.

Sinha, J. B. P. (1982). Power in Indian organizations. Indian Journal of Industrial Relations, Vol. 17, 339-352.

Taylor, H.R. (1986). Power at work. Personnel Journal, April, Vol 65(4), 47.49.

Templer, A. J. (1984). Measuring managerial power: A South African cross-cultural validation. South African Journal of Psychology, June, Vol. 14(2), 43-49. As Abstracted in the American Psychological Abstracts, 1985, July, Vol. 72(7). 
Vempati, R., and Krishnan, V. R. (2000). Power and influence strategies: An analysis across departments. NMIMS Management Review, 12 (1), January-June, 51-61.

Ward, E. A. (1998). Managerial power bases and subordinates' manifest needs as influences on psychological climate. Journal of Business and Psychology, Vol. 12(3), March, 361-378.

Wilson, P. A. (1999). A theory of power and politics and their effects on organizational commitment of senior executive service members. Administration and Society, Vol. $31(1), 120-141$.

Wilson, P. A. (1995). The effects of politics and power on the organizational commitment of federal executives. Journal of Management, Vol. 21(1), 101-118.

Winter, D. G. (1973). The Power Motive. The Free Press, 1973.

Yagil, D. (2002). Substitution of a leader's power bases by contextual variables. International Journal of Organization Theory and Behaviour. Vol. 5(3 and 4), 383-399.

Yukl, G. (2006). Leadership in Organizations, 6th Edition, Pearson Education, Inc, and Dorling Kindersley Publishing Inc.

Zalezink, A. (1970). Power and politics in organizational life. Harvard Business Review, May-Jun. 